\title{
Exploitation Versus Advocation: A Case Study of Hill Land Use in Bandar Lampung City
}

\author{
Bendi Juantara \\ Government Science \\ Lampung University \\ Lampung, Indonesia \\ bendi.juantara@fisip.unila.ac.id
}

\author{
Pitojo Budiono \\ Government Science \\ Lampung University \\ Lampung, Indonesia \\ pitojo.budiono@fisip.unila.ac.id
}

\author{
Darmawan Purba \\ Government Science \\ Lampung University \\ Lampung, Indonesia \\ darmawan.purba@fisip.unila.ac.id
}

\begin{abstract}
Bandar Lampung City is facing serious problems related to the massive exploitation of hill land which has an impact on landslides and floods. To achieve the objective of this study, the researcher uses a descriptive qualitative approach including advocacy and movement analysis and data collection techniques using observation, documentation, and literature review. The results of the study show that most of the hill objects are controlled and become legal private ownership rights. On this basis, landowners carry out land-use changes and take economic value from the exploitation of the hill. Non-Government Organizations (NGOs) such as Walhi and Mitra Bentala have carried out various advocacy efforts to pressure local governments so that hill land tenure can be taken over for the sake of environmental conservation. However, the advocacy aspect that has been carried out has not been effective because the contestation in building a pro-environment policy narrative is experiencing difficult challenges. Therefore, the need for political will and firmness from regional heads and related stakeholders in developing hill management policies based on rationality principles, containing truth values and justice.
\end{abstract}

Keywords-Exploitation, NGO Advocacy, Bukit Kota Bandar Lampung

\section{INTRODUCTION}

The existence of hills as water catchment areas is very important because they function to maintain balance and sustainability of water systems, especially in the preservation of groundwater and prevent floods and droughts [1]. However, the condition of the hills in the area is now not as beautiful as previously imagined. The hills have been damaged due to exploitation. Since the birth of regional autonomy, land use and tenure, have become objects of contention by many parties. Unsurprisingly, hill areas have triggered conflicts of interest between mining, land use, and conservation land [2]. If the hill area is damaged, it will not be easy to rehabilitate. Article 67 of Law No.32/2009 concerning Environmental Protection and Management (UUPPLH) stated that "Everyone is obliged to preserve environmental functions and control environmental pollution and/or damage", but in practice, environmental management activities are far from the rules instructed.

Based on Regional Regulation No. 1/1996 concerning Management of Slopes, Hills and Mountains in Bandar Lampung by Mayor Decree No.33/1996, which was revised by Regional Regulation No. 4/2004 concerning Spatial Planning for the City of Bandar Lampung, it is stated that the Bandar Lampung City has 11 (eleven) hills as conservation areas, namely; Mount Sulah (Sukarame); Turmeric Mountain (South Betung Bay); Gunung Sari (Central Coral Cape); Cat Mountain (West Coral Cape); Mount Banten (Kedaton); Mount Boat (Kedaton); Mount Sukamenanti (Kedaton); Klutum Hill (East Cape Coral); Randu Hill (East Coral Cape), Kapuk Hill (East Coral Cape) and Camang Hill (East Coral Cape). However, these conservation areas have been damaged. According to data from Indonesian Forum for the Environment (Walhi), Bandar Lampung City has a total of 33 hills, but since 1990, these hills have been exploited massively. It was recorded that until 2019 the hills level damage in Bandar Lampung City reached more than $80 \%$, as the level of damage from light, moderate, to heavy damage.

The high activity of hill exploitation in Bandar Lampung City has triggered environmental degradation. Uncontrolled scouring of hills has eliminated urban groundwater catchment areas, as a result, floods are now unavoidable. Bandar Lampung City has experienced three (3) major flood disasters, namely in the year: 1998, 2008 to 2013, the flood resulted in 6000 houses being heavily and lightly damaged also causing casualties. Even in the year 20162019, the intensity, area, and volume of floods are getting higher and higher until they reach the urban center area. This flood incident has also damaged public infrastructures such as facilities for health, education, housing, and places of worship. 
The emergence of hill damage and the increasingly acute flood disaster in Bandar Lampung City have triggered deep concern. The government, as the main actor, has a central role in unraveling these public problems, but this role has seemed to be eliminated. Though, the government is indicated to have participated as part of the mastermind behind the scouring of the hills. In the concept of Governance, there are 3 (three) domains of actors who should work and collaborate, namely the government, Civil Society, and the Private Sector. The government in this case is no longer the dominant actor but becomes one of the actors who play a role in determining public problems. Other domains such as Civil Society should be taken into account for the balance between actors, including taking into account the role of Non-Government Organizations (NGOs).

NGOs related to the environment in Bandar Lampung City have made various advocacy attempts to reduce the level of environmental damage in the city of Bandar Lampung. Somehow, in reality, it has not been seen the result of the advocacy to stop the practice of exploiting hill land in Bandar Lampung City. Therefore, based on the explanation above, this study has the purpose to look at the reality of NGOs in advocating damage to hill land due to exploitation in Bandar Lampung City.

\section{LITERATURE REVIEW}

This study uses a combination of the four elements of Margaret and Sikkink's transnational advocacy network [4] as follows:

\section{A. Information Politic}

Information plays an important role in binding group membership, creating effective work in a network, and can be used as a tool that can influence the public on the issues being fought for. Therefore, this study will look at how the media is used by NGOs in finding, collecting, managing, and distributing credible sources of information so that they are politically useful to support hill land conservation in Bandar Lampung City.

\section{B. Symbolic System}

In the context of advocating for the exploitation of hill land in Bandar Lampung City, an appropriate method is needed so that what is being fought for can be achieved. Concerning the persuasion process to increase elite and public awareness, in this case, how do NGOs package symbolic events through actions, symbols, or stories so that they can convince the public to support hill land conservation efforts in the city of Bandar Lampung?

\section{Leverage Politic}

Following the definition of political effectiveness which highlights material and moral support from powerful actors, therefore in this context how are NGO efforts in seeking material and moral support from powerful institutions and actors who can support hill land conservation efforts in the city of Bandar Lampung

\section{Accountability Politics}

After going through the various efforts above, then at this point, how are the NGO efforts in binding, and maintaining commitment and consistency on the availability of actors in supporting the hill land conservation effort in the city of Bandar Lampung

In terms of opening up the state of the art space, this research has conducted various literature studies with similar studies, the first is the research of Muhammad Arief Virgy et al with the title Greenpeace Indonesia Transnational Advocacy Network Strategy Regarding the Issue of Deforestation in Indonesia by Wilmar International. This study highlights Wilmar International as the perpetrator of deforestation. The results of this study indicate that Greenpeace Indonesia is very optimal in carrying out Information Politics and Leveraging Politics strategies.

Greenpeace Indonesia has a creative and confrontational method in implementing the Symbolic Politics strategy. However, the weakness of this strategy is that Greenpeace Indonesia seems exclusive in carrying out its actions by other environmental NGOs, especially environmental NGOs with a domestic base. The weakness of these four strategies is Accountability Politics where Greenpeace Indonesia does not have a commitment from Wilmar International which has binding legal force so that Greenpeace Indonesia only relies on public pressure to pressure Wilmar International to commit to implementing the NDPE policy.

The research above is linear with the research conducted by Moh. Arief Rakhman et al with the title Dynamics of the Role of Environmental NGOs in the Local Political Arena in Jambi Province. This research is motivated by a phenomenon shown by environmental NGOs working in the environmental field, where Jambi province has several distributions that cannot be said to be small. Environmental NGOs in Jambi operate in various networks, ranging from local, national to the international scale. The form, nature, and strength of each of these networks determine the future sustainability of the Environmental NGO sector in Jambi and Indonesia more broadly. This study explains the function of environmental NGOs as political forces that emerge and can exert a strong influence on the policy-making process in the realm of local government. The research adheres to the constructivism paradigm by using a qualitative approach to provide explanations and understand events that are or have occurred, which emphasizes the interpretation of the meaning of categories that develop from research informants. The results of this study are expected to understand how the strategies and achievements of environmental NGOs in Jambi in providing policies related to the environment. 
In particular, NGO advocacy can be seen from the environmental policy politics of WALHI South Sulawesi (a study on Environmental Policy Advocacy in Kunciopao District, Gowa Regency) by Nawir. The results of the study indicate that WALHI South Sulawesi plays a role as a strategic partner of the government and the community, both from the formulation stage to the policy evaluation stage. In addition, this study also shows that the obstacles experienced by WALHI South Sulawesi in conducting environmental advocacy lie in 2 sectors, namely Internal and External. Internally, it consists of Human Resources and Financial Resources, while externally consists of Government and Law Enforcement.

Another thing we can see is the Mining Advocacy Network Movement (JATAM) as an Intermediary Actor in controlling environmental damage due to postcoal mining and to find out the problems faced by the Mining Advocacy Network (JATAM) in implementing the Movement as an Intermediary Actor in controlling environmental damage due to post-mining coal. The results obtained in this study are that the emergence of Jatam is a reaction to the weak control role of the government in meeting the needs and fulfilling the rights of the community as citizens, and or the limitations of the community in fulfilling their demands to the state or government. So that in the end the role was carried out by Jatam in bridging between the community and the state and fighting for the rights of the people who were neglected by the government.

Jatam carried out its movement by garnering support from the public such as conducting campaigns and creating petitions to increase the existing mass to support Jatam in overcoming the problem of mining pits as well as urging and suing the government for being negligent and irresponsible. The political movement carried out by Jatam also has an impact on public awareness at large to participate directly or indirectly in solving the problem of mining pits, the movement initiated by Jatam is also able to trigger public anger about ecological threats and the threat of death from mining pits in East Kalimantan.

\section{RESEARCH METHODS}

The research method used in this research is descriptive. In this research, the descriptive method is used to analyze: 1). Identify the 33 hill objects in Bandar Lampung City related to land conversion activities, the level of damage, to the perceived impact; 2) See the reality of advocacy that has been carried out by Non-Government Organizations (NGOs) to end the exploitation of hill land in Bandar Lampung City. The bigger the problem of the hills in Bandar Lampung City, indicates that the government is no longer the main actor, but as one of the actors from other domains that work together, be it civil society or the private sector. This research will look at the reality of NGOs in advocating the destruction of hill land due to exploitation in Bandar Lampung City.
Methods of data collection are by conducting field observations, unstructured interviews, documentation, and literature review. The observations results that have been obtained, starting from data collection, are identifying and mapping the hill area of Bandar Lampung City. Furthermore, the literature (review) on the efforts that have been made by the government of Lampung Province and Bandar Lampung City to suppress the exploitation of this hill land, such as the Lampung Provincial Regulation No. 1/2010 concerning the Regional Spatial Plan (RTRW) of Lampung Province in the year 2009-2029, Lampung Province Regional Regulation No. 3/2006 concerning Management of Natural Resources and the Environment, and Bandar Lampung City Regional Regulation No. 10/2011 concerning Regional Spatial Planning for 2011-2030. Next, identifying the level of collaboration between actors and NGOs environmental watchdog organizations, as well as identifying the inhibiting factors for the implementation of collaboration, and finally, identifying the effectiveness and efficiency of collaboration in monitoring redistributive policies for the exploitation of hill land in Bandar Lampung City.

\section{RESULTS AND DISCUSSION}

\section{A. Portrait of Bandar Lampung City Hill Exploitation}

The exploitation of natural resources in Indonesia has been carried out in a massive, structured, and systematic manner in almost all regions. This exploitative paradigm was strengthened due to Indonesia's interest in increasing economic stability and growth. Various policies with a centralized, top-down, and exploitative economic approach are implemented in such away. Most of the policies are even accommodate more to the interests of investors/capital owners to control and exploit all the economic potential of natural resources down to the smallest level (in the regions). This privilege can be seen from the lack of serious, sharp, and critical, also through political debates in the natural resource management policy process. If any, it is only political rhetoric where everything is dominated by lobbying and compromise [3].

Local governments have an important role in regulating and managing the potential of regional resources (SDA) in their regions, both from coastal areas to mountainous areas. Control and management are important because these landscapes have interrelated and mutually supportive relationships to maintain environmental ecosystems. Unfortunately, these landscape relationships and functions are often discarded and converted into economic and development commodities. This can be seen from the basics of successful regional development today, which refers to the ease of investment and regional competitiveness. Indirectly, the criteria for the success of this development trigger the destruction of natural 
resources. The market principle has become the main domain as a forum for the utilization and allocation of natural resources (SDA) that works on the amount of capital. This can be seen from a large number of land tenures by certain individuals and groups with legal (certified) legality. The impact of this ease of investment, in the end, raises irony, where the area that invests the most gives occur to many regional disasters, including one in Bandar Lampung City.

Bandar Lampung City has an area of 19,722 ha with hilly and coastal contours. Viewed from the total area mentioned above, Bandar Lampung City should have a Green Open Space (RTH) with a minimum total area of 5,916 ha consisting of Public Green Open Space (RTH) or government-owned land of at least 3,944 ha (20\% of the total area of Bandar Lampung City). Unfortunately, based on WaLHI Lampung Province analysis, it shows that there has been a change in land cover related to the area/space that has been designated as Green Open Space. A total of 102.43 ha or equivalent to $29.76 \%$ of Green Open Space (RTH) in Bandar Lampung City experienced a change in land use or conversion. This change in land use has made Green Open Space (RTH) experience a significant decline.

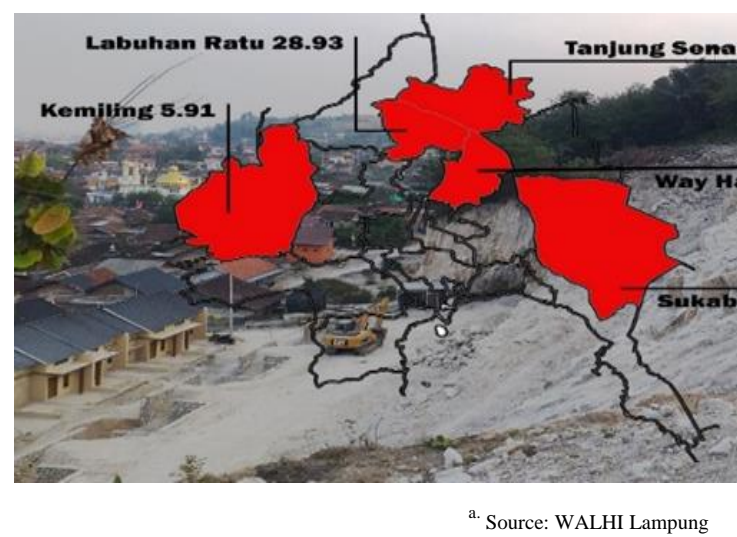

Fig. 1. Location of Land Transfer in Bandar Lampung.

Based on WALHI's result analysis, currently, the condition of the Green Open Space (RTH) of Bandar Lampung City which was originally an area of 344.156 ha has changed functions and only an area of 241.82 ha remains due to land conversion. WALHI identifies 5 (five) Green Open Spaces (RTH) that experiences the biggest changes in the infographic, namely Way Kandis, Kemiling, Gunung Sulah, Sukabumi, and Labuhan Ratu areas. If the remaining green open space is added to the components of Zoo, Agricultural Land, SUTET, Median Road \& Pedestrian, and Green Line, the total remaining Bandar Lampung City Green Open Space is $1,743.05$ hectares or equivalent to $9.31 \%$.

The practice of land conversion on hill or mountain objects in the city of Bandar Lampung is identified as 4 (four) main activities of exploitation. The first is mining, housing, tourism, and settlement activities. The practice of exploiting hills by dredging and taking stones and soil has been going on for a long time, even the depletion of hills in the city of Bandar Lampung is the result of these mining activities. Based on field observations, several hills in Bandar Lampung City have suffered severe damage due to mining practices. Some of these hills are Langgar Hill, Balau Hill, Turmeric Mountain, Klutum Hill, East Camang Hill, Foot Hill of Mount Betung, Hatta Hill, Sukamenanti Hill, and boat mountain (Field Observation Results).

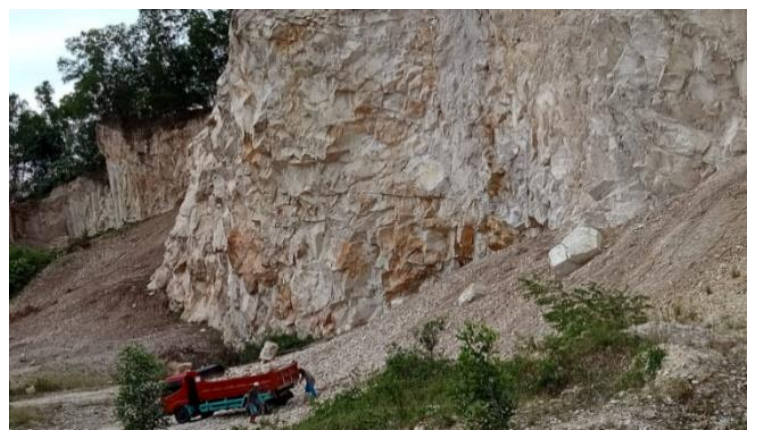

Fig. 2. Loading and Unloading of Rocks in the Middle of the Hill Location.

Mining activities in the hill area have a very high economic value, therefore mining practices occur massively in several areas both legally and illegally. So far, mining practices are still taking place at several hill points, one of which is the hill in the Sukamenanti area. Although the area has been notified as a green open space area, mining practices are still being carried out. Based on the field observation results, the mining in the Sukamenanti hill area used heavy equipment until 2019. When the mining process was still using heavy equipment, 50 to 100 vehicles carried the excavated products. However, since the practice of mining heavy equipment was stopped, traditional miners continue to mine by producing an average of 2-10 vehicles a day. On average, the workers are local people who do not have particular jobs and only use the hill location as a place to earn a living.

Unfortunately, often the people are only used as a reason by the landowners so that the landowners do not pay taxes and permits, the hill mining management rights are managed together with the surrounding community so that the landowners can take profits without paying obligations. What's even more worrying is that after the hill mining, the remaining area is flat and well-ordered. The existence of a new flat area will bring tremendous benefits to the landowner. The economic value of the hill object can increase to ten times compared to the price of a hill. In addition to mining, other hill land conversion activities are tourism objects, restaurants, and hotels/inns. In addition, many hill locations have been turned into elite residential areas. 

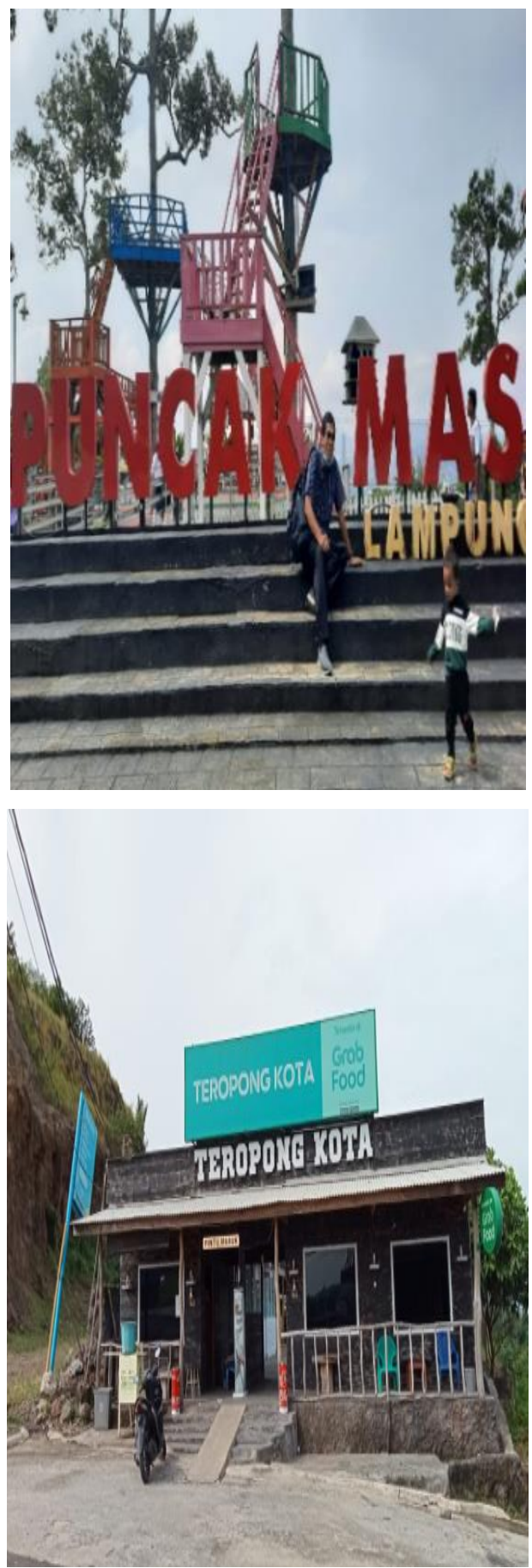

Fig. 3. Location of Hill Tourism Objects

The damage of hills widespread exploitation in Bandar Lampung City has left a major impact. The erosion of the hill's position has indirectly led to the loss of absorption and water capture capacity, also to the loss of the hill ecological function, thus leading to potential ecological disasters, especially floods and landslides. Based on the 2019 Bandar Lampung City Flood Disaster Research, almost half of the Bandar Lampung area was flooded. In addition, based on Walhi data, shows that there have been landslides at Mount
Perahu Hill and Bukit Kaliawi in 2020. Thus, 3 (three) out of 7 (seven) children were killed while swimming in a pool excavated from a rock mine located in Camping Raya Village, Sukabumi District, Bandar Lampung City. This tragedy happened due to the land being excavated from a mine area that was not managed properly. Not to mention the destruction of the hills has caused changes in urban and regional planning that are increasingly chaotic and complicated. In the end, the chance for the City of Bandar Lampung to achieve Kalpataru becomes not as likely.

Therefore, rationality and ethics in the contestation of each regional policy narrative are indispensable in supporting the balance of environmental narratives amid the currents of economic hegemony. Unfortunately, the contestation of the proenvironmental actor movement that is rational and ethical is not as strong as other groups of actors who will take advantage. Various cross-community joint actions are not so much supported by the community. This is common because of the low support and involvement of the community due to elements such as the loss of public trust, reputation, and accountability of leadership so far. In the end, regulation becomes the main focus as a counterweight, even though it is not certain that the regulation can run and be able to solve environmental problems. In this context, this research will discuss the reality of the advocacy from the NGOs WALHI, and Mitra Bentala in fighting for environmental sustainability.

\section{B. The reality of $\mathrm{NGO}$ advocacy in environmental conservation efforts}

The exploitation of Bukit Land in Bandar Lampung City is concerning. Most of the hill area is controlled privately by certain individuals or groups. This hill land tenure has the potential to experience exploitation of land conversion. Advocacy movements carried out by local governments and non-government organizations are needed to balance social and political domains to save hill areas from the clutches of conglomerates. However, this advocacy effort is not an easy matter. The local government as the main actor in the practice of governance and development finds it difficult to regulate land use. It is common since the contestation of hill land tenure is related to the wealth in the hill area.

The massive private ownership of hill land and high exploitation activity in Bandar Lampung City shows the frailty of the government's supervisor function in protecting the hill area. Bandar Lampung City Government as a hill administration area in Bandar Lampung City needs to have policy innovations to synchronize the interests between parties. Simultaneously, concrete steps are needed to encourage the alignment of environmental, social, and economic variables in viewing a hill object in Bandar Lampung City. The exploitation of the hills should not only be seen from an economic point of view but also the negative impact on the environment and society. The 
breakthrough of the Regional Head who is innovative and decisive is eagerly awaited to unravel the hill problem. On the other hand, the NGOs have a strategic role to politically impose the policies made by the government to reduce hill damage.

\section{1) Advocacy for NGO Wahana Lingkungan Hidup} (WALHI)

The Indonesian Forum for the Environment is an Environmental Movement Organization in Indonesia. WALHI is located in 28 provinces in Indonesia which has 502 Member Organizations, Institutional Members, and more than 200 Individual Members. In International, WALHI networked and became a member of the International Federation of Friends of the Earth, and International Environmental Organization that is actively working at the grassroots and exists in 74 countries in the world which has 174 member organizations in the world and has more than 2 million sympathizers in the world.

WALHI Lampung's Strategic Goals for the year 2019-2023 are: First, increasing legal awareness from various elements of society and law enforcement to realize fair and sustainable natural resources \& environmental management. Second, spatial planning policy takes into account the carrying capacity and capacity of the environment as well as the protection of essential ecosystem areas as part of adaptation, mitigation of ecological disasters, and climate change. And third, the realization of good and accountable Lampung WALHI Organizational Governance. The issues advocated by WALHI Lampung are classified into 5 (five) priority issues, namely: Forests and largescale plantations, coastal and small islands, mining and energy, water, rivers and industry, urban and ecological disasters

WALHI is one of the environmental NGOs that is consistent in its role as a suppressor function. This role is reflected in efforts to control, prevent, and stem the government's domination and manipulation of the community. This role is generally carried out through policy advocacy through lobbying, political statements, petitions, and demonstrations. The role as a counterweight to the government includes the role of influencing public policy, as a means of government checks and balances, filling the role of social development that is not carried out by the government, and complementing the role of the state as a public servant.

WALHI sees recently environmental issues in Bandar Lampung City as a minor matter in a political context, especially the hill issue. Policies related to the environment are often less concerned than other policy aspects such as development and economic policies. The government of Bandar Lampung is incapable of surging the private sector or landowners to contribute to environmental sustainability. The absence of local government support for the Bandar Lampung city can be seen from the Vision and Mission implementation from the regional head to the political will of the regional head himself to be more concerned and firm with the landowners.

To advocate for hill sustainability, WALHI takes concrete steps in a policy paper by providing the following recommendations:

- Maintaining the remaining hills in Bandar Lampung City and conducting a moratorium on extractive permits in the hill areas in Bandar Lampung City and maintaining them by the mandate of the Regional Regulation on RTRW of Bandar Lampung City.

- Increasing the Quality and Quantity of Green Open Space in Bandar Lampung City and maintaining the existing green open space with various schemes and policies so that Bandar Lampung can meet the green open space target of at least $30 \%$ according to the mandate of the legislation.

- Stop granting permits to planned activities that are the land-use change that will change the protection function and/or conservation function in the Bandar Lampung City area.

- Implementing law enforcement and giving strict sanctions against corporations and/or industries that violate the environment, spatial planning, and activities that hurt the community in Bandar Lampung City.

\section{2) Advocacy for NGO Mitra Bentala}

NGO Mitra Bentala Established on April 9, 1995. This environmental organization concentrates on PELA and KDP issues. The purpose of this organization is to reduce the damage of ecosystems in coastal areas (mangroves, seagrass beds, coral reefs), maintain the existence of integrated and sustainable management of marine coastal natural resources; (Policies/rules), and increase the participation of coastal communities in "empowerment".

The NGO Mitra Bentala sees that the hill area in the city of Bandar Lampung is private land that is legally certified. Hence, any activity related to the hill is the developer's authority. In some cases, several hill points are used by developers as an object of mining for stone materials that contain selling value and housing. The NGO Mitra Bentala sees that in this case, the Bandar Lampung City government is unable to cope with the conglomerate because of its dominant power. Therefore, the NGO Mitra Bentala has tried to encourage various studies on hills in Bandar Lampung City as aspects of supporting community life (SDG's). In addition, the NGO Mitra Bentala encourages all Bukit objects in Bandar Lampung City to be purchased and become local government assets that can provide benefits for all, not just for individual ownership or 
certain groups. NGO Mitra Bentala also opens a space for socialization and education to the community regarding the importance of hills ecological function. Nonetheless rejects the conversion of Bukit Bandar Lampung and rejects the reclamation of Lampung Bay using Bukit Camang.

\section{CONCLUSION}

The results of the study show that the hill objects in Bandar Lampung City are mostly controlled and become legal private ownership rights. On this basis, landowners carry out land-use changes and take economic value from the exploitation of the hill. NGOs such as Walhi and Mitra Bentala have made various advocacy efforts to urge local governments so that hill land tenure can be undertaken for environmental conservation. However, the advocacy aspect that has been carried out has not been effective because the contestation in building a pro-environment policy narrative is experiencing difficult challenges, where there needs to be political will and firmness from regional heads and related stakeholders in developing hill management policies based on rationality principles, containing truth values, and justice.

\section{REFERENCES}

[1] Maheasy, M. R, Analysis of Water Catchment Areas Using Landsat 8 Imagery And Geographic Information Systems (Doctoral Dissertation, In Malang), 2017.

[2] Wibowo, M, Model of Determination of Water Catchment Areas for Environmentally Friendly Spatial Planning. Indonesian Journal of Hydrosphere, 1(1), 2019.

[3] Kurniawan, D, Relationship of Land Use to Infiltration (Case Study: Bukittinggi Mayor's Office Area). Rang Engineering Journal, 1(1), 2018.

[4] Adji, T. N., \& Haryono, E, Karst Areas and Prospects for Its Development in Indonesia, 2017.

[5] Haryono, E., \& in the National Seminar, M, The hydrological value of karst hills. Source, 10, 20-6, 2001

[6] Saeng, Valentinus CP, Herbeth Mercure: peranhg semesta melawan kapitalisme Global. PT. Gramedia Pustaka Utama, 2012.

[7] Keck, M.E \& Sikkink K, Activist Beyond Borders: Advocacy Network In International Politics. London (Cornell University Press), 1998.

[8] Law of the Republic of Indonesia Number 32 of 2009 concerning Environmental Protection and Management.

[9] Law Number 26 of 2007 concerning Spatial Planning.

[10] Lampung Province Regional Regulation Number 1 of 2010 concerning the Regional Spatial Plan (RTRW) of Lampung Province from 2009 to 2029.

[11] Bandar Lampung City Regulation Number 10 of 2011 concerning Regional Spatial Planning for 2011-2030. 